\title{
Tandem Synthesis of Furanaphthoquinones via Enamines and Evaluation of Their Antiparasitic Effects against Trypanosoma cruzi
}

\author{
Mariana F. C. Cardoso, ${ }^{\circledR \#, a}$ Luana S. M. Forezi, ${ }^{\circledR \#, a}$ Acácio S. de Souza, ${ }^{\circledR a}$ \\ Ana F. M. Faria, ${ }^{b}$ Raissa M. S. Galvão ${ }^{b}$ Murilo L. Bello, ${ }^{c}$ Fernando C. da Silva, ${ }^{\circledR a}$ \\ Robson X. Faria ${ }^{\circledR *, b, d}$ and Vitor F. Ferreira ${ }^{\circledR *, e}$ \\ ${ }^{a}$ Departamento de Química Orgânica, Instituto de Química, Universidade Federal Fluminense, \\ 24210-141 Niterói-RJ, Brazil \\ ${ }^{b}$ Programa de Pós-Graduação em Ciências e Biotecnologia, Departamento de Biologia, \\ Instituto de Biologia, Universidade Federal Fluminense, 24210-141 Niterói-RJ, Brazil \\ 'Laboratório de Planejamento Farmacêutico e Simulação Computacional, Faculdade de Farmácia, \\ Universidade Federal do Rio de Janeiro, 21941-599 Rio de Janeiro-RJ, Brazil \\ ${ }^{d}$ Laboratório de Avaliação e Promoção da Saúde Ambiental, Instituto Oswaldo Cruz (FIOCRUZ), \\ 21045-900 Rio de Janeiro-RJ, Brazil \\ ${ }^{e}$ Departamento de Tecnologia Farmacêutica, Faculdade de Farmácia, \\ Universidade Federal Fluminense, 24241-000 Niterói-RJ, Brazil
}

\begin{abstract}
Furanaphthoquinones are well known in medicinal chemistry for exhibiting relevant structural heterogeneity and bioactivities. In this work, it was synthesized a series of furanaphthoquinones through a tandem reaction between lawsone $(\mathbf{8})$ and cyclic ketones in the presence of morpholine. This strategy provides an efficient and general method for synthesizing furanaphthoquinones with activity against the epimastigote form of Trypanosoma cruzi (T. cruzi), the parasite that causes Chagas disease. Compound $\mathbf{9 b}$ was the better prototype, and it exhibited high potency for causing parasite death, showed reduced acute toxicity towards mammalian cells, and was capable of rupturing the epimastigote plasma membrane and acting on sterol $14 \alpha$-demethylase (CYP51). Additionally, $\mathbf{9 b}$ reduced trypomastigote viability by $99 \%$ after $24 \mathrm{~h}$. Candidate $\mathbf{9 b}$ demonstrated the best and most promising profile when bound to CYP51.
\end{abstract}

Keywords: quinones, lawsone, lapachones, Chagas disease, neglected diseases

\section{Introduction}

Medicinal chemistry has significantly contributed to the search for new drugs that can improve the quality of life of patients affected by various diseases. However, socalled neglected tropical diseases lack clinically effective drugs, and more research needs to be conducted to find new prototypes that can be transformed into drugs. Today, more than one billion people, one-sixth of the world's population, are suffering from neglected tropical diseases. ${ }^{1}$ Chagas disease, caused by the protozoan $T$. cruzi, is a neglected tropical disease with high prevalence and

*e-mail: robson.xavier@gmail.com; vitorferreira@id.uff.br \#Equally first author.

Editors handled this article: Teodoro S. Kaufman and Brenno A. D. Neto (Associate) significant morbidity and mortality. The treatment of Chagas disease is still based on only two drugs, nifurtimox and benznidazole, both of which have limited efficacy in the late chronic phase, cause frequent side effects, and have evolved drug resistance.

In this context, naphthoquinones are considered promising structures in the field of medicinal chemistry, as their antitrypanosomal potential has been reported. ${ }^{1}$ These compounds are associated with various biochemical processes in microorganisms such as fungi and bacteria and higher plants and animals. These compounds are involved in respiratory chain electron transport, energy production, coagulation, and blood cells. Naphthoquinone structural diversity and its similarities to endogenous molecules demonstrate that these compounds can treat and cure diseases caused by pathogenic microorganisms. ${ }^{1-4}$ Research 
groups have attempted to promote structural modifications in the naphthoquinone core in search of compounds with a better spectrum of action against $T$. cruzi. Thus, some naphthoquinones, such as 1-3, and their derivatives, such as $\mathbf{4}$, have been reported in the literature ${ }^{5-9}$ to have activity against $T$. cruzi (Scheme 1a). Continuing our interest in the synthesis of naphthoquinones that can be used against $T$. cruzi, the etiologic agent of Chagas disease, we decided to study the reaction between lawsone (5a) and cyclic ketones $\mathbf{8}$ in the presence of morpholine to form furanaphthoquinones 9 via in situ formation of intermediate enamine (Scheme 1c). 1,4-Naphthoquinones can react with enamine 6 to produce furanaphthoquinone 7 (Scheme 1b). ${ }^{10-14}$ However, enamines must be prepared in advance. This work describes a tandem reaction involving lawsone (5a), ketones (8), and morpholine, with the in situ formation of enamines, to produce furanaphthoquinones $\mathbf{9}$; the trypanocidal activity of the new compounds against the epimastigote forms of T. cruzi was also evaluated.

\section{Experimental}

\section{Chemistry}

Analytical grade solvents (Biograde, São Paulo, Brazil) were used. Column chromatography was performed using silica gel (SilicaFlash ${ }^{\circledR}$ P60 0.040-0.063 mm, Silicycle,
São Paulo, Brazil). Melting points (mp) were obtained on a Thermo Scientific 9100 apparatus (Waltham, USA) and were uncorrected. Infrared spectra (IR) were recorded on a Shimadzu IR Prestige-21 FTIR spectrometer (Kyoto, Japan) in KBr tablet (Sigma-Aldrich, São Paulo, Brazil). The reactor used to perform the reactions in the closed vessel was a Berghof model BR-300 (Eningen, Germany). ${ }^{1} \mathrm{H}$ and ${ }^{13} \mathrm{C}$ nuclear magnetic resonance (NMR) spectra were recorded at room temperature using a VNMRSYS-500 (Palo Alto, USA) or a Varian MR 300 instrument (Palo Alto, USA), using the solvents indicated, with tetramethylsilane (TMS) as the internal standard. Chemical shifts $(\delta)$ are given in ppm, and coupling constants $(J)$ are given in hertz $(\mathrm{Hz})$. High-resolution mass spectra (HRMS) were recorded on a MICROMASS Q-TOF mass spectrometer (Milford, USA).

\section{General procedure for preparation of $9 a-9 c$ and $10 a-10 c$}

A $125 \mathrm{~mL}$ round bottom flask containing a solution of morpholine (11.4 mmol), ketone $(\mathbf{8}, 13.77 \mathrm{mmol})$, and $p$-toluenesulfonic acid (PTSA, $1.14 \mathrm{mmol}$ ) in toluene $(40 \mathrm{~mL})$ was refluxed for $5 \mathrm{~h}$ in a Dean-Stark apparatus. After this, 2-hydroxy-1,4-naphthoquinone (5a, $5.74 \mathrm{mmol}$ ) was added in portions, and reflux was maintained for more $2 \mathrm{~h}$ followed by another $12 \mathrm{~h}$ of stirring at room temperature. Then, the solvent was removed under reduced pressure, and

(a) Naphthoquinones with activities against $T$.cruzi<smiles>[R]C1=C(Oc2cc(C)ccc2OC2=C(Br)C(=O)c3ccccc3C2=O)C(=O)c2ccccc2C1=O</smiles>

(b) Reaction of naphthoquinones with enamine

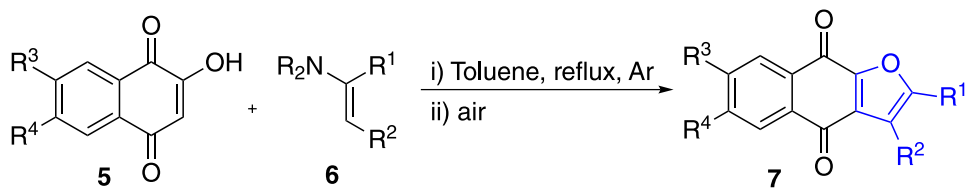

(c) This work: Synthesis of furanaphthoquinones via in situ formation of enamine.<smiles>[R]C1CCC(=O)CC1</smiles>

Scheme 1. Some anti-T. cruzi naphthoquinones and synthesis of furanaphthoquinones from enamines. 
the residue was purified by column chromatography on silica gel using a mixture of hexane:acetone as the gradient.

\section{1,2,3,4-Tetrahydronaphtho[2,3-b]benzofuran-6,11-dione} (9a)

Yellow solid (840 mg, $3.33 \mathrm{mmol}, 58 \%$ ); mp $195197^{\circ} \mathrm{C}$; IR (KBr) $v / \mathrm{cm}^{-1} 1656,1639,1619,1584,1573,1500,1402$, $1218,1160,829 ;{ }^{1} \mathrm{H}$ NMR $\left(500.00 \mathrm{MHz}, \mathrm{CDCl}_{3}\right) \delta 1.80-$ $1.85(2 \mathrm{H}, \mathrm{m}), 1.90-1.95(2 \mathrm{H}, \mathrm{m}), 2.77(2 \mathrm{H}, \mathrm{t}, J 6.10 \mathrm{~Hz})$, $2.82(2 \mathrm{H}, \mathrm{t}, J 6.30 \mathrm{~Hz}), 7.68-7.74(2 \mathrm{H}, \mathrm{m}), 8.12-8.14(1 \mathrm{H}$, m), 8.18-8.20 (1H, m); ${ }^{13} \mathrm{C} \mathrm{NMR}\left(125.00 \mathrm{MHz}, \mathrm{CDCl}_{3}\right) \delta$ 21.4, 22.3, 23.6, 118.8, 126.7, 129.5, 132.8, 133.5, 133.8, 142.2, 151.2, 159.9, 173.3, 182.2; HRESIMS $\mathrm{m} / z$, calcd. for $\mathrm{C}_{16} \mathrm{H}_{12} \mathrm{O}_{3} \mathrm{Na}^{+}[\mathrm{M}+\mathrm{Na}]^{+}:$275.0679, found: 275.0680; $\Delta 0.4 \mathrm{ppm}$.

2-Methyl-1,2,3,4-tetrahydronaphtho[2,3-b]benzofuran6,11-dione (9b)

Yellow solid ( $826 \mathrm{mg}, 3.10 \mathrm{mmol}, 54 \%)$; $\mathrm{mp} 187-189^{\circ} \mathrm{C}$; IR (KBr) $v / \mathrm{cm}^{-1} 1687,1649,1618,1584,1583,1478,1400$, 1214, 1150, 820; ${ }^{1} \mathrm{H}$ NMR $\left(500.00 \mathrm{MHz}, \mathrm{CDCl}_{3}\right) \delta 1.13$ $(3 \mathrm{H}, \mathrm{d}, J 6.7 \mathrm{~Hz}), 1.22(1 \mathrm{H}, \mathrm{s}), 1.53-1.61(2 \mathrm{H}, \mathrm{m}), 2.32-2.38$ $(1 \mathrm{H}, \mathrm{m}), 2.72-2.86(2 \mathrm{H}, \mathrm{m}), 3.01(1 \mathrm{H}, \mathrm{dd}, J 16.7,5.07 \mathrm{~Hz})$, 7.68-7.74 (2H, m), 8.12-8.14 (1H, m), 8.18-8.20 (1H, m); ${ }^{13} \mathrm{C}$ NMR $\left(125.00 \mathrm{MHz}, \mathrm{CDCl}_{3}\right) \delta 21.1,23.1,28.9,29.4$, $30.3,118.3,126.7,129.4,132.8,133.3,133.5,133.8,151.4$, 159.8, 173.3, 182.2; HRESIMS $m / z$, calcd. for $\mathrm{C}_{17} \mathrm{H}_{14} \mathrm{O}_{3} \mathrm{Na}^{+}$ $[\mathrm{M}+\mathrm{Na}]^{+}: 289.0835$, found: $289.0834 ; \Delta 0.3 \mathrm{ppm}$.

2-(tert-Butyl)-1,2,3,4-tetrahydronaphtho[2,3-b]benzofuran6,11-dione (9c)

Yellow solid (885 mg, $2.87 \mathrm{mmol}, 50 \%)$; mp 207-209 ${ }^{\circ} \mathrm{C}$; IR (KBr) $v / \mathrm{cm}^{-1} 1694,1656,1614,1588,1582,1477,1405$, $1212,1160,822 ;{ }^{1} \mathrm{H} N M R\left(500.00 \mathrm{MHz}, \mathrm{CDCl}_{3}\right) \delta 2.12-2.15$ $(1 \mathrm{H}, \mathrm{m}), 2.36-2.39(10 \mathrm{H}, \mathrm{m}), 2.43-2.44(1 \mathrm{H}, \mathrm{m}), 2.65-2.72$ $(1 \mathrm{H}, \mathrm{m}), 2.85-2.88(1 \mathrm{H}, \mathrm{m}), 2.98-3.02(2 \mathrm{H}, \mathrm{m}), 7.67-7.72$ $(2 \mathrm{H}, \mathrm{m}), 8.10-8.11(1 \mathrm{H}, \mathrm{m}), 8.16-8.18(1 \mathrm{H}, \mathrm{m}) ;{ }^{13} \mathrm{C} \mathrm{NMR}$ $\left(125.00 \mathrm{MHz}, \mathrm{CDCl}_{3}\right) \delta 21.1,23.9,25.0,27.2,27.3,28.4$, 29.7, 112.3, 126.7, 128.1, 131.2, 133.8, 134.8, 136.4, 152.3, 157.0, 185.6, 185.9; HRESIMS $m / z$, calcd. for $\mathrm{C}_{20} \mathrm{H}_{20} \mathrm{O}_{3} \mathrm{Na}^{+}$ $[\mathrm{M}+\mathrm{Na}]^{+}:$331.1305, found: $331.1288 ; \Delta 5.1 \mathrm{ppm}$.

2-(Cyclohex-1-en-1-yl)-3-hydroxynaphthalene-1,4-dione (10a)

Orange solid (584 mg, $2.30 \mathrm{mmol}, 40 \%$ ); $\mathrm{mp} 230-233^{\circ} \mathrm{C}$; IR $(\mathrm{KBr}) \vee / \mathrm{cm}^{-1} 1699,1691,1653,1650,1628,1614$, $1588,1454,1430,1217,1203,818 ;{ }^{1} \mathrm{H}$ NMR $(500.00 \mathrm{MHz}$, $\left.\mathrm{CDCl}_{3}\right) \delta 1.64-1.73(4 \mathrm{H}, \mathrm{m}), 2.16-2.21(4 \mathrm{H}, \mathrm{m}), 5.77(1 \mathrm{H}$, m), 7.61 (1H, td, J 7.5, 1.3 Hz), 7.69 (1H, td, J 7.56, $1.3 \mathrm{~Hz})$, $8.03(2 \mathrm{H}$, ddd, $J 15.6,7.7,1.0 \mathrm{~Hz}) ;{ }^{13} \mathrm{C}$ NMR $(125.00 \mathrm{MHz}$, $\left.\mathrm{CDCl}_{3}\right) \delta 22.6,24.1,26.0,27.7,114.5,121.6,125.5,126.6$
127.6, 127.9, 130.8, 138.4, 144.3, 178.2, 182.8; HRESIMS $m / z$, calcd. for $\mathrm{C}_{16} \mathrm{H}_{14} \mathrm{O}_{3} \mathrm{Na}^{+}[\mathrm{M}+\mathrm{Na}]^{+}: 277.0835$, found: 277.0822; $\Delta 4.7 \mathrm{ppm}$.

2-Hydroxy-3-(4-methylcyclohex-1-en-1-yl)-naphthalene1,4-dione (10b)

Orange solid (585 mg, $2.18 \mathrm{mmol}, 38 \%)$; $\mathrm{mp} 212-215^{\circ} \mathrm{C}$; IR $(\mathrm{KBr}) \vee / \mathrm{cm}^{-1} 1699,1685,1658,1650,1616,1610$, $1590,1452,1430,1222,1174,821 ;{ }^{1} \mathrm{H}$ NMR $(500.00 \mathrm{MHz}$, $\left.\mathrm{CDCl}_{3}\right) \delta 1.05(3 \mathrm{H}, \mathrm{s}), 1.35-1.75(6 \mathrm{H}, \mathrm{m}), 5.01(1 \mathrm{H}, \mathrm{d}$, J 7.8 Hz), 7.55-7.66 (2H, m), 7.95-7.99 (2H, m); ${ }^{13} \mathrm{C} \mathrm{NMR}$ $\left(125.00 \mathrm{MHz}, \mathrm{CDCl}_{3}\right)$ \& 21.3, 24.5, 26.7, 29.9, 43.4, 115.3, $126.1,127.3,127.8,128.9,129.5,134.6,140.6,150.3$, 184.8, 187.9; HRESIMS $m / z$, calcd. for $\mathrm{C}_{17} \mathrm{H}_{16} \mathrm{O}_{3} \mathrm{Na}^{+}$ $[\mathrm{M}+\mathrm{Na}]^{+}:$291.0992, found: 291.0990; $\Delta 0.7 \mathrm{ppm}$.

2-(4-(tert-Butyl)cyclohex-1-en-1-yl)-3-hydroxynaphthalene1,4-dione (10c)

Orange solid (749 mg, $2.41 \mathrm{mmol}, 42 \%$ ); $\mathrm{mp} 224-227^{\circ} \mathrm{C}$; IR $(\mathrm{KBr}) \vee / \mathrm{cm}^{-1} 1712,1697,1662,1660,1620,1603$, $1591,1460,1432,1226,1198,837 ;{ }^{1} \mathrm{H}$ NMR $(500.00 \mathrm{MHz}$, $\left.\mathrm{CDCl}_{3}\right) \delta 0.84(9 \mathrm{H}, \mathrm{s}), 1.18(1 \mathrm{H}, \mathrm{s}), 1.30$ (1H, ddd, J 24.5, $12.2,4.8 \mathrm{~Hz}), 1.37-1.43(1 \mathrm{H}, \mathrm{m}), 1.83-1.87(1 \mathrm{H}, \mathrm{m}), 1.93-$ $2.01(1 \mathrm{H}, \mathrm{m}), 2.15-2.22(2 \mathrm{H}, \mathrm{m}), 5.81-5.82(1 \mathrm{H}, \mathrm{s}), 7.61$ $(1 \mathrm{H}, \mathrm{td}, J 7.5,1.3 \mathrm{~Hz}), 7.69(1 \mathrm{H}, \mathrm{td}, J 7.6,1.3 \mathrm{~Hz}), 8.03(2 \mathrm{H}$, ddd, $J 16.1,7.7,0.8 \mathrm{~Hz}) ;{ }^{13} \mathrm{C}$ NMR $\left(125.00 \mathrm{MHz}, \mathrm{CDCl}_{3}\right)$ $\delta$ 22.4, 22.7, 22.9, 31.6, 33.9, 36.7, 48.2, 66.2, 116.4, 123.5, 127.5, 128.6, 129.5, 129.9, 132.8, 140.3, 146.3, 170.7, 178.4; HRESIMS $m / z$, calcd. for $\mathrm{C}_{20} \mathrm{H}_{22} \mathrm{O}_{3} \mathrm{Na}^{+}[\mathrm{M}+\mathrm{Na}]^{+}$: 333.1461 , found: $333.1446 ; \Delta 4.5 \mathrm{ppm}$.

\section{General procedure for preparation of 11a-11c}

To a $50 \mathrm{~mL}$ round bottom flask containing $10(0.34 \mathrm{mmol})$, $10 \mathrm{~mL}$ of concentrated sulfuric acid was carefully added dropwise. The mixture was stirred at room temperature for $10 \mathrm{~min}$ and then poured onto ice, forming a precipitate in an aqueous medium. The suspension was extracted with ethyl acetate, the organic layer was dried with anhydrous sodium sulfate, and the solvent was removed under reduced pressure. The residue was purified by column chromatography on silica gel using hexane/ethyl acetate as the eluent.

7,8,9,10-Tetrahydronaphtho[1,2-b]benzofuran-5,6-dione (11a)

Red solid (58 mg, $0.23 \mathrm{mmol}, 68 \%$ ); mp $178-180{ }^{\circ} \mathrm{C}$; IR (KBr) v / cm ${ }^{-1} 1703,1672,1653,1650,1615,1600$, $1581,1456,1428,1223,1200,832 ;{ }^{1} \mathrm{H}$ NMR $(500.00 \mathrm{MHz}$, $\left.\mathrm{CDCl}_{3}\right) \delta 1.58-1.68(4 \mathrm{H}, \mathrm{m}), 2.11-2.16(4 \mathrm{H}, \mathrm{m}), 7.57(1 \mathrm{H}$, td, $J 7.5,1.3 \mathrm{~Hz}), 7.64(1 \mathrm{H}, \mathrm{td}, J 7.5,1.3 \mathrm{~Hz}), 7.98(2 \mathrm{H}$, ddd, $J 15.7,7.6,1.0 \mathrm{~Hz}) ;{ }^{13} \mathrm{C}$ NMR $\left(125.00 \mathrm{MHz}, \mathrm{CDCl}_{3}\right)$ 
$\delta 25.5,26.3,27.9,29.7,100.2,118.0,126.9,129.3,131.3$, 132.8, 132.9, 134.9, 151.6, 159.7, 181.9, 184.0; HRESIMS $m / z$, calcd. for $\mathrm{C}_{16} \mathrm{H}_{12} \mathrm{O}_{3} \mathrm{Na}^{+}[\mathrm{M}+\mathrm{Na}]^{+}: 275.0679$, found: $275.0671 ; \Delta 2.9 \mathrm{ppm}$.

8-Methyl-7,8,9,10-tetrahydronaphtho[1,2-b]benzofuran5,6-dione (11b)

Red solid (59 mg, 0.22 mmol, 65\%); mp 155-157 ${ }^{\circ} \mathrm{C}$; IR $(\mathrm{KBr}) \vee / \mathrm{cm}^{-1} 1722,1680,1668,1655,1612,1605$, 1577, 1450, 1421, 1217, 1206, 817; ${ }^{1} \mathrm{H} \mathrm{NMR}(500.00 \mathrm{MHz}$, $\left.\mathrm{CDCl}_{3}\right) \delta 1.13(3 \mathrm{H}, \mathrm{d}, J 6.7 \mathrm{~Hz}), 1.40(1 \mathrm{H}, \mathrm{dtd}, J 13.3$, $10.4,5.5 \mathrm{~Hz}), 1.58(1 \mathrm{H}, \mathrm{s}), 1.85-1.90(1 \mathrm{H}, \mathrm{m}), 2.27(1 \mathrm{H}$, dddd, $J$ 16.5, 9.3, 2.8, 2.0 Hz), 2.59-2.66 (1H, m), 2.75$2.85(2 \mathrm{H}, \mathrm{m}), 7.38(1 \mathrm{H}, \mathrm{td}, J 7.5,1.5 \mathrm{~Hz}), 7.60(2 \mathrm{H}, \mathrm{dtd}$, $J$ 8.9, 7.6, $1.2 \mathrm{~Hz}), 8.01(1 \mathrm{H}, \mathrm{dd}, J 7.7,0.6 \mathrm{~Hz}) ;{ }^{13} \mathrm{C} \mathrm{NMR}$ $\left(125.00 \mathrm{MHz}, \mathrm{CDCl}_{3}\right) \delta 25.5,26.8,28.7,35.0,39.7,101.2$, $117.8,129.2$, 130.9, 133.7, 135.3, 136.9, 138.6, 152.7, 158.7, 179.4, 184.5; HRESIMS $m / z$, calcd. for $\mathrm{C}_{17} \mathrm{H}_{14} \mathrm{O}_{3} \mathrm{Na}^{+}$ $[\mathrm{M}+\mathrm{Na}]^{+}:$289.0835, found: $289.0827 ; \Delta 2.8 \mathrm{ppm}$.

8-(tert-Butyl)-7,8,9,10-tetrahydronaphtho[1,2-b]benzofuran5,6-dione (11c)

Red solid (65 mg, $0.21 \mathrm{mmol}, 62 \%)$; mp 193-196 ${ }^{\circ} \mathrm{C}$; IR $(\mathrm{KBr}) \vee / \mathrm{cm}^{-1} 1684,1671,1666,1658,1627,1614$, 1581, 1447, 1415, 1209, 1200, 821; ${ }^{1} \mathrm{H}$ NMR (500.00 MHz, $\left.\mathrm{CDCl}_{3}\right) \delta 1.81(9 \mathrm{H}, \mathrm{s}), 1.93(1 \mathrm{H}, \mathrm{dd}, J 24.7,11.6 \mathrm{~Hz}), 2.18$ $(1 \mathrm{H}, \mathrm{d}, J 11.2 \mathrm{~Hz}), 2.53-2.59(1 \mathrm{H}, \mathrm{m}), 3.00-3.04(2 \mathrm{H}, \mathrm{m})$, 4.21-4.24 (1H, m), 4.38-4.44 (1H, m), 7.95 (2H, dtd, J 25.9, 7.4, $1.2 \mathrm{~Hz}), 8.30-8.33$ (2H, m); ${ }^{13} \mathrm{C}$ NMR (125.00 MHz, $\left.\mathrm{CDCl}_{3}\right) \delta 28.8,30.1,31.7,33.6,38.3,100.4,116.7,130.3$, $131.8,132.2$, 133.0, 135.8, 136.7, 164.0, 169.2, 184.2, 191.6; HRESIMS $m / z$, calcd. for $\mathrm{C}_{20} \mathrm{H}_{20} \mathrm{O}_{3} \mathrm{Na}^{+}[\mathrm{M}+\mathrm{Na}]^{+}$: 331.1305, found: $331.1301 ; \Delta 1.2 \mathrm{ppm}$.

\section{General procedure for preparation of $\mathbf{1 2 a - 1 2 c}$}

A $50 \mathrm{~mL}$ round bottom flask containing a mixture of 9a-9c $(0.6 \mathrm{mmol})$, acetic anhydride $(106 \mathrm{mmol})$, pyridine (3 drops) and $\mathrm{Zn}^{0}(0.6 \mathrm{mmol})$ was incubated with stirring at room temperature for 4 days. Then, the mixture was filtered, and the solution was extracted with dichloromethane, washed with saturated sodium bicarbonate solution, and dried with anhydrous sodium sulfate. The solvent was then removed under reduced pressure.

1,2,3,4-Tetrahydronaphtho[2,3-b]benzofuran-6,11-diyl diacetate (12a)

Yellow solid (193 mg, $0.76 \mathrm{mmol}, 95 \%$ ); mp 223-225 ${ }^{\circ} \mathrm{C}$; IR (KBr) $v / \mathrm{cm}^{-1} 1698,1693,1659$, 1655, 1611, 1591, 1588, 1464, 1415, 1218, 1169, 818; ${ }^{1} \mathrm{H}$ NMR (500.00 MHz, $\left.\mathrm{CDCl}_{3}\right) \delta 1.74-1.78$ (2H, m), 1.84-
$1.88(2 \mathrm{H}, \mathrm{m}), 2.30(6 \mathrm{H}, \mathrm{s}), 2.70(2 \mathrm{H}, \mathrm{t}, J 6.3 \mathrm{~Hz}), 2.75$ $(2 \mathrm{H}, \mathrm{t}, J 6.3 \mathrm{~Hz}), 7.61-7.67(2 \mathrm{H}, \mathrm{m}), 8.05-8.06(1 \mathrm{H}, \mathrm{m})$, 8.11-8.13 (1H, m); ${ }^{13} \mathrm{C} \mathrm{NMR}\left(125.00 \mathrm{MHz}, \mathrm{CDCl}_{3}\right) \delta 23.9$, 32.6, 34.9, 117.4, 124.5, 126.5, 128.5, 130.9, 131.7, 133.8, 137.7, 141.3, 151.3, 160.9, 171.7, 183.3; HRESIMS $m / z$, calcd. for $\mathrm{C}_{20} \mathrm{H}_{18} \mathrm{O}_{5} \mathrm{Na}^{+}[\mathrm{M}+\mathrm{Na}]^{+}: 361.1046$, found: $361.1043 ; \Delta 0.8 \mathrm{ppm}$.

2-Methyl-1,2,3,4-tetrahydronaphtho[2,3-b]benzofuran6,11-diyl diacetate (12b)

Yellow solid (341 mg, $0.97 \mathrm{mmol}, 97 \%)$; $\mathrm{mp} \mathrm{218-220}{ }^{\circ} \mathrm{C}$; IR $(\mathrm{KBr}) \vee / \mathrm{cm}^{-1} 1701,1688,1654,1650,1615,1581$, 1576, 1474, 1419, 1221, 1185, 830; ${ }^{1} \mathrm{H}$ NMR (500.00 MHz, $\left.\mathrm{CDCl}_{3}\right) \delta 1.06(3 \mathrm{H}, \mathrm{d}, J 6.6 \mathrm{~Hz}), 2.11-2.14(1 \mathrm{H}, \mathrm{m}), 2.19-$ $2.21(1 \mathrm{H}, \mathrm{m}), 2.35-2.38(1 \mathrm{H}, \mathrm{m}), 2.43(3 \mathrm{H}, \mathrm{s}), 2.46(3 \mathrm{H}$, s), 2.71-2.75 (4H, m), 7.36-7.41 (2H, m), $7.77(1 \mathrm{H}, \mathrm{dd}$, $J$ 7.2, $2.0 \mathrm{~Hz}), 7.85(1 \mathrm{H}, \mathrm{dd}, J 7.1,2.1 \mathrm{~Hz}) ;{ }^{13} \mathrm{C} \mathrm{NMR}$ $\left(125.00 \mathrm{MHz}, \mathrm{CDCl}_{3}\right) \delta 20.9,22.9,28.8,29.2,30.1,30.3$, $118.6,126.6,128.2,129.3,132.6,133.2,133.4,133.6$, 135.8, 151.3, 159.6, 173.1, 182.0; HRESIMS m/z, calcd. for $\mathrm{C}_{21} \mathrm{H}_{20} \mathrm{O}_{5} \mathrm{Na}^{+}[\mathrm{M}+\mathrm{Na}]^{+}:$375.1203, found: 375.1199; $\Delta 1.1 \mathrm{ppm}$.

2-(tert-Butyl)-1,2,3,4-tetrahydronaphtho[2,3-b]benzofuran6,11-diyl diacetate (12c)

Yellow solid (218 mg, $0.55 \mathrm{mmol}, 92 \%)$; $\mathrm{mp} 232-235^{\circ} \mathrm{C}$; IR $(\mathrm{KBr}) v / \mathrm{cm}^{-1} 1710,1677,1650,1648,1617,1595,1578$, 1465, 1421, 1226, 1191, 828; ${ }^{1} \mathrm{HNMR}\left(500.00 \mathrm{MHz}, \mathrm{CDCl}_{3}\right)$ $\delta 1.13(9 \mathrm{H}, \mathrm{d}, J 6.7 \mathrm{~Hz}), 1.43(1 \mathrm{H}, \mathrm{s}), 1.53-1.61(2 \mathrm{H}, \mathrm{m})$, 1.89-2.01 (2H, m), 2.32-2.38 (1H, m), $2.50(6 \mathrm{H}, \mathrm{s}), 3.01(1 \mathrm{H}$, dd, $J 16.7,5.1 \mathrm{~Hz}), 7.68-7.74(2 \mathrm{H}, \mathrm{m}), 8.12-8.14(1 \mathrm{H}, \mathrm{m})$, 8.18-8.20 (1H, m); ${ }^{13} \mathrm{C}$ NMR (125.00 MHz, $\left.\mathrm{CDCl}_{3}\right) \delta 20.5$, 20.8, 21.1, 22.8, 24.9, 26.0, 27.4, 29.8, 32.0, 40.1, 114.6, 121.7, 125.6, 126.7, 127.7, 128.1, 134.9, 138.5, 144.5, 168.1, 168.9, 177.1, 189.7; HRESIMS $m / z$, calcd. for $\mathrm{C}_{24} \mathrm{H}_{26} \mathrm{O}_{5} \mathrm{Na}^{+}$ $[\mathrm{M}+\mathrm{Na}]^{+}:$417.1678, found: 417.1670; $\Delta 1.9 \mathrm{ppm}$.

\section{General procedure for preparation of $13 \mathbf{a}-\mathbf{1 3 c}$}

In a $600 \mathrm{~mL}$ high-pressure reactor (Berghof, Model BR-300), a solution in ethanol $(200 \mathrm{~mL})$ of 9 (4 mmol) and $\mathrm{Pd} / \mathrm{C}(10 \mathrm{~mol} \%)$ was stirred under 27 psi pressure of hydrogen for $10 \mathrm{~min}$. Then, the mixture was filtered, and the solvent was removed under reduced pressure. The residue was purified by column chromatography on silica gel using hexane/ethyl acetate as the eluent.

$6 \mathrm{~b}, 7,8,9,10,10 a-H e x a h y d r o n a p h t h o[1,2-b]$ benzofuran5,6-dione (13a)

Orange solid (356 mg, $1.40 \mathrm{mmol}, 35 \%)$; $\mathrm{mp} 152-153^{\circ} \mathrm{C}$; IR $(\mathrm{KBr}) \vee / \mathrm{cm}^{-1} 1715,1667,1655,1636,1614,1611$, 
$1577,1465,1420,1218,1211,820 ;{ }^{1} \mathrm{H} \mathrm{NMR}(500.00 \mathrm{MHz}$, $\left.\mathrm{CDCl}_{3}\right) \delta 1.69-1.75(4 \mathrm{H}, \mathrm{m}), 2.21-2.23(4 \mathrm{H}, \mathrm{m}), 2.91-2.94$ $(1 \mathrm{H}, \mathrm{m}), 3.12-3.15(1 \mathrm{H}, \mathrm{m}), 7.65(1 \mathrm{H}, \mathrm{td}, J 7.5,1.2 \mathrm{~Hz})$, $7.73(1 \mathrm{H}, \mathrm{td}, J$ 7.6, $1.3 \mathrm{~Hz}), 8.07$ (2H, ddd, $J$ 16.1, 7.7, $0.8 \mathrm{~Hz}) ;{ }^{13} \mathrm{C} \mathrm{NMR}\left(125.00 \mathrm{MHz}, \mathrm{CDCl}_{3}\right) \delta 21.8,22.6$, 25.5, 27.9, 56.9, 63.5, 118.1, 125.9, 126.9, 128.6, 132.8, 132.9, 134.9, 172.2, 181.9, 184.0; HRESIMS $m / z$, calcd. for $\mathrm{C}_{16} \mathrm{H}_{14} \mathrm{O}_{3} \mathrm{Na}^{+}[\mathrm{M}+\mathrm{Na}]^{+}:$277.0835, found: 277.0822 ; $\triangle 4.7 \mathrm{ppm}$.

8-Methyl-6b,7,8,9,10,10a-hexahydronaphtho[1,2-b]benzofuran-5,6-dione (13b)

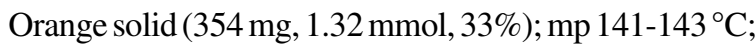
IR $(\mathrm{KBr}) \vee / \mathrm{cm}^{-1} 1703,1664,1660,1650,1620,1611$, $1581,1449,1425,1210,1206,815 ;{ }^{1} \mathrm{H} \mathrm{NMR}(500.00 \mathrm{MHz}$, $\left.\mathrm{CDCl}_{3}\right) \delta 1.27(3 \mathrm{H}, \mathrm{d}, J 6.7 \mathrm{~Hz}), 1.50-1.58(1 \mathrm{H}, \mathrm{m}), 1.72$ $(1 \mathrm{H}, \mathrm{s}), 1.99-2.04(1 \mathrm{H}, \mathrm{m}), 2.38-2.44(1 \mathrm{H}, \mathrm{m}), 2.73-2.80$ (1H, m), 2.99-2.89 (2H, m), 2.87-2.77 (2H, m), 3.12-3.14 $(1 \mathrm{H}, \mathrm{m}), 3.32-3.35(1 \mathrm{H}, \mathrm{m}), 7.52(1 \mathrm{H}, \mathrm{td}, J 7.5,1.5 \mathrm{~Hz})$, $7.74(2 \mathrm{H}, \mathrm{dtd}, J 8.9,7.6,1.2 \mathrm{~Hz}), 8.15(1 \mathrm{H}, \mathrm{dd}, J 7.7$, $0.6 \mathrm{~Hz}) ;{ }^{13} \mathrm{C} \mathrm{NMR}\left(125.00 \mathrm{MHz}, \mathrm{CDCl}_{3}\right) \delta 21.5,22.6,24.7$, 31.0, 35.7, 60.4, 66.6, 113.8, 125.2, 127.0, 129.7, 131.3, 132.9, 134.6, 170.3, 175.4, 180.5; HRESIMS $m / z$, calcd. for $\mathrm{C}_{17} \mathrm{H}_{16} \mathrm{O}_{3} \mathrm{Na}^{+}[\mathrm{M}+\mathrm{Na}]^{+}:$291.0992, found: 291.0977 ; $\triangle 5.1 \mathrm{ppm}$.

8-(tert-Butyl)-6b,7,8,9,10,10a-hexahydronaphtho[1,2-b]benzofuran-5,6-dione (13c)

Orange solid (372 mg, $1.20 \mathrm{mmol}, 30 \%) ; \mathrm{mp} 174-177^{\circ} \mathrm{C}$; IR $(\mathrm{KBr}) \vee / \mathrm{cm}^{-1} 1720,1671,1659,1651,1625,1613$, 1588, 1453, 1420, 1215, 1212, 819; ${ }^{1} \mathrm{H} \mathrm{NMR}(500.00 \mathrm{MHz}$, $\left.\mathrm{CDCl}_{3}\right) \delta 1.57(9 \mathrm{H}, \mathrm{s}), 1.65-1.72(1 \mathrm{H}, \mathrm{m}), 1.94(1 \mathrm{H}, \mathrm{d}$, $J 11.2 \mathrm{~Hz}), 2.29-2.35$ (1H, m), 2.76-2.80 (2H, m), 3.75 $(1 \mathrm{H}, \mathrm{d}, J 7.7 \mathrm{~Hz}), 3.97-4.00(1 \mathrm{H}, \mathrm{m}), 4.14-4.20(1 \mathrm{H}, \mathrm{m})$, $5.19(1 \mathrm{H}, \mathrm{d}, J 7.7 \mathrm{~Hz}), 7.71(2 \mathrm{H}, \mathrm{dtd}, J 25.9,12.0,7.4 \mathrm{~Hz})$, 8.06-8.09 (2H, m); $\left.{ }^{13} \mathrm{C} \mathrm{NMR} \mathrm{(125.00} \mathrm{MHz,} \mathrm{CDCl}_{3}\right) \delta 26.9$, 28.1, 29.7, 31.6, 42.4, 60.8, 65.9, 114.7, 128.3, 129.8, 130.2, 131.0, 133.8, 134.7, 170.6, 177.6, 182.2; HRESIMS $m / z$, calcd. for $\mathrm{C}_{20} \mathrm{H}_{22} \mathrm{O}_{3} \mathrm{Na}^{+}[\mathrm{M}+\mathrm{Na}]^{+}: 333.1461$, found: $333.1466 ; \Delta 1.5 \mathrm{ppm}$.

\section{Biological assays}

Cell culture

\section{Mouse peritoneal macrophages}

These cells were obtained after peritoneal lavage from adult Swiss-Webster male mice (mass of 20-30 g). It was applied $10 \mathrm{~mL}$ of phosphate buffered saline (PBS) per animal, and the collected supernatant was centrifuged and plated. It was used animal breeding units in the Hélio and
Pegy Pereira pavilions at FIOCRUZ/IOC under license number L039-2016.

\section{Cultures of parasites}

Epimastigote forms of T. cruzi (strain Y) were maintained in liver infusion tryptose (LIT) medium at $28^{\circ} \mathrm{C}$ and through weekly passages. The mice were infected with trypomastigotes of $T$. cruzi obtained after metacyclogenesis in LIT medium at $28^{\circ} \mathrm{C}$ to obtain the necessary parasite number for animal infection. The infected cells were maintained at $34{ }^{\circ} \mathrm{C}$ with $\mathrm{CO}_{2}$. Parasites purified from the blood were resuspended in Dulbecco's modified Eagle's medium (DMEM) supplemented with $20 \%$ fetal bovine serum (FBS).

\section{T. cruzi (Y strain - bloodstream trypomastigotes)}

Trypomastigotes were obtained from the blood samples of infected albino Swiss mice at the peak of parasitemia. The purified parasites were resuspended in DMEM (SigmaAldrich, São Paulo, Brazil) supplemented with 10\% FBS as reported previously. ${ }^{8,9}$

Vero cells were cultured in Roswell Park Memorial Institute (RPMI) medium supplemented with 5\% FBS, $100 \mathrm{UI} \mathrm{mL}^{-1}$ antibiotic mixture, and $10 \mu \mathrm{g} \mathrm{mL}^{-1}$ streptomycin at $37^{\circ} \mathrm{C}$ in an atmosphere of $5 \% \mathrm{CO}_{2}$ until the cells reached $90 \%$ confluence. The cell monolayer was infected with trypomastigotes ( $\mathrm{Y}$ strain, 10 parasites per cell). After $24 \mathrm{~h}$, the supernatant medium was collected, and Vero cells and amastigotes were removed by centrifugation at $1000 \mathrm{~g}$ for $5 \mathrm{~min}$. Trypomastigotes were collected by centrifugation at $1600 \mathrm{~g}$ for $10 \mathrm{~min}$.

Trypanocidal activity in trypomastigotes and amastigotes (Y strain) was determined using $1 \times 10^{6}$ cells $\mathrm{mL}^{-1}$ in 96 -well plates and incubation at $37^{\circ} \mathrm{C}$ for $24 \mathrm{~h}$ in the presence of the corresponding drug. Trypomastigote viability was determined by counting in a Neubauer chamber.

Cell metabolism activity test (Redox) in vitro using the resazurin reduction technique

Peritoneal macrophages derived from Swiss Webster strain mice were obtained through peritoneal lavage. The cell suspension contained in the supernatant was centrifuged at $1500 \mathrm{rpm}$ for $5 \mathrm{~min}$. The pellet was resuspended in $1 \mathrm{~mL}$ RPMI medium and counted in a Neubauer chamber. A total of $4 \times 10^{5}$ macrophages well ${ }^{-1}$ were seeded in triplicate in 96-well plates with RPMI medium supplemented with $10 \%$ FBS. These cells were incubated in an oven at $37{ }^{\circ} \mathrm{C}$ in a humidified atmosphere of $5 \% \mathrm{CO}_{2}$ for $24 \mathrm{~h}$. After the cells adhered for $24 \mathrm{~h}$, all the media was removed, and the compounds were added to plates in SFP-free (Shahidi Ferguson Perfringens free) 
RPMI medium at 6 concentrations equal to $0.01,0.1,1$, 25,50 , and $100 \mu \mathrm{M}$ using a final volume of $200 \mu \mathrm{L}$ well ${ }^{-1}$. As a negative control, the wells were maintained only with cells and culture medium. It was used $0.5 \%$ Triton X-100 (Sigma-Aldrich, São Paulo, Brazil) as a positive control. The plates were incubated again for $24 \mathrm{~h}$, and after that interval, the colorimetric assay was performed by reducing resazurin (RZ, Sigma-Aldrich, São Paulo, Brazil). A volume of $100 \mu \mathrm{L}$ of the supernatant was removed from each well, and $20 \mu \mathrm{L}$ of RZ $\left(0.15 \mathrm{mg} \mathrm{mL}^{-1}\right)$ was added. The plates were incubated again for $4 \mathrm{~h}$, and the readings were obtained in a spectrophotometer at 575 and $595 \mathrm{~nm}$ using SoftMax Pro software (version 5.1). ${ }^{15}$ Data analysis was performed using GraphPad Prism 5. ${ }^{16}$

In vitro cell toxicity assay using the lactate dehydrogenase $(\mathrm{LDH})$ release technique

After the treatment mentioned above in peritoneal macrophages, a volume of $50 \mu \mathrm{L}$ was collected from each well and transferred to a new plate. A substrate mix prepared according to the manufacturer's specifications (Promega, Wisconsin, USA) was added and incubated for $30 \mathrm{~min}$. After this time, the reaction stop reagent was added, and immediately afterwards, the absorbance was read in a spectrophotometer at $490 \mathrm{~nm}$ using SoftMax Pro software (version 5.1)..$^{15}$

\section{Determination of trypanocidal action}

The $T$. cruzi culture incubated for $24 \mathrm{~h}$ in LIT medium was added to a 96-well plate at $1 \times 10^{6}$ cells per $200 \mu \mathrm{L}$. It was added a $1 \mu \mathrm{M}$ concentration of each compound and $20 \mu \mathrm{L}$ of $0.2 \mu \mathrm{M}$ propidium iodide solution for $30 \mathrm{~min}$. The fluorescence was quantified as arbitrary fluorescence units of non-viable cells in a SpectraMax M4 spectrophotometer (Molecular Devices, California, United States of America) at 565-605 nm wavelengths. Triton X-100 (Sigma-Aldrich, São Paulo, Brazil) was used as a trypanocidal control, and the culture without compound addition was used as a negative control. All treatments were performed in triplicate.

\section{Spectroscopic CYP51 $1_{\mathrm{TC}}$ binding assay}

Spectrophotometric titration was used for binding assays. A volume of $3 \mathrm{~mL}$ of $50 \mathrm{mM}$ Tris- $\mathrm{HCl}(\mathrm{pH} \mathrm{7.5)}$ and $10 \%$ glycerol was used in a UV-visible (UV-Vis) scanning spectrophotometer (Varian, Palo Alto, United States of America). The CYP51Tc (sterol 14 $\alpha$-demethylase from T. cruzi) concentration used was $0.1 \mu \mathrm{M}$. Stock solutions of $9 \mathbf{a}, 9 \mathbf{b}, 9 \mathbf{c}, \mathbf{1 1 a}$ and $11 \mathbf{b}$ were solubilized in dimethyl sulfoxide (DMSO, Sigma-Aldrich, São Paulo, Brazil) at $20 \mu \mathrm{M}$. Titrations were performed using a $3.5 \mathrm{~mL}$ quartz cuvette with a path length of $1 \mathrm{~cm}$, and the inhibitor was added to $300 \mu \mathrm{L}$ aliquots. As a negative control, DMSO was added in the same amounts, and the difference spectra were measured. KD (dissociation constant) values recorded for data titration of points were fitted to quadratic hyperbola using GraphPad Prism software (GraphPad Software Inc. $),{ }^{16}$ as follows: $\mathrm{A}_{\mathrm{obs}}=(\mathrm{Amax} / 2 \times \mathrm{Et})\{(\mathrm{S}+\mathrm{Et}+\mathrm{KD})-$ $[(\mathrm{S}+\mathrm{Et}+\mathrm{KD}) 2-4 \times \mathrm{S} \times \mathrm{Et}] 0.5\}$, where $\mathrm{A}_{\mathrm{obs}}$ is the absorption change determined at any inhibitor concentration, Amax is the maximal absorption shift recorded at saturation, $\mathrm{KD}$ is the dissociation constant for the inhibitor-enzyme complex, Et is the total enzyme concentration used, and $\mathrm{S}$ is the inhibitor concentration.

In silico

\section{Molecular modeling of ligands}

The compounds of the series 9-11 were initially built using the program Avogadro. ${ }^{17,18}$ The geometry optimizations of molecules were then performed using the MMFF94 (Merck molecular force field 94). The optimized conformers were submitted to refinement calculations of the geometry optimization using the semiempirical parametric method PM6 performed by the MOPAC2016 program. $^{19}$

\section{Molecular docking}

The program Molegro Virtual Docker (MVD) ${ }^{20}$ was used to perform molecular docking (CLC Bio, 8200, Aarhus, Denmark). The MolDock score algorithm [GRID] with a grid resolution of $0.30 \AA$ was selected as the score function, and the partial charges were assigned according to the MVD charge scheme. The MolDock Optimizer algorithm was used with a search space of $32 \AA$ around the $T$. cruzi protein CYP51 structure. The CYP51 protein structure (PDB code: 4CK9) was retrieved from the Protein Data Bank (PDB). Molecular docking of the MC series compounds was performed using the same parameter set (runs $=100$, population size $=50$, max interactions $=2000$, scaling factor $=0.50$, and crossover rate $=0.90$ ). The ligand poses were selected based on MolDock score values. Both the Molegro Virtual Docker ${ }^{18}$ and PyMOL $^{21}$ were used to visualize and analyze the optimized molecular complexes.

\section{Protein/ligand binding enthalpy}

Molecular complexes of MC series compounds and T. cruzi 14- $\alpha$-lanosterol demethylase (CYP51) obtained by docking and separate optimized ligands with protein before docking were applied to MOZYME calculation using a dielectric constant of 78.4. The calculations were performed using the MOPAC2016 program to indicate the molecular system heat of formation $\left(\Delta \mathrm{H}_{\mathrm{f}}\right) .{ }^{17-23}$ Protein CYP51 and heme 
group atom coordinates were fixed. For ligand molecules, geometry optimization was freely allowed.

\section{Results and Discussion}

\section{Chemistry}

Initially, through a reaction between 2-hydroxy1,4-naphthoquinone (5a) and enamine, generated in situ from ketone $\mathbf{8}$ under acid catalysis of PTSA, we obtained a mixture of lapachone $9 \mathbf{a}-9 \mathbf{b}$ and adduct $\mathbf{1 0 a - 1 0 c}$ without the formation of furan-1,2-naphthoquinones 11a-11c. However, when 10a-10b were stirred in concentrated sulfuric acid for $10 \mathrm{~min}$, it was obtained furan-1,2-naphthoquinones 11a-11c in moderate yields (Scheme 2).

The possible mechanism of this reaction is stopped by the nucleophilic attack of enamine formed in situ, leading to intermediate II after oxidation of quinol and elimination of morpholine, resulting in furan1,4-naphthoquinones 9a-9c. This mechanism had already been reported by Kobayashi et al. ${ }^{11}$ in a reaction between 2-hydroxy-1,4-naphthoquinones and previously synthesized enamines (Scheme 3).
The strategy used to improve the solubility of quinones in the biological environment, and therefore for them to be formulated to reach the biological target, is to transform them into diacetylated derivatives. Reichstein et al. ${ }^{24}$ showed that metabolically labile furan-1,4-naphthoquinones were designed as prodrugs and were only slightly less active than their parent naphthoquinone counterparts in suppressing keratinocyte hyperproliferation in the micromolar range. In addition, Ma et $a l .{ }^{25}$ reported the preclinical evaluation of prodrug derivatives of $\beta$-lapachone encapsulated in biocompatible and biodegradable poly(ethylene glycol)- $\beta$-poly(D-lactic acid) (PEG- $\beta$ PLA) micelles. These formulations were used for the treatment of non-small cell lung cancers (NSCLC) that overexpress nicotinamide adenine dinucleotide phosphate $(\mathrm{NAD}(\mathrm{P}) \mathrm{H})$ :quinone oxidoreductase 1 (NQO1) and demonstrated efficiencies $>95 \%$ with significantly reduced hemolysis and methemoglobinemia that currently limits ARQ761 formulations.

To promote small changes in the furanaphthoquinone nucleus that transform the compounds into more soluble substances in biological media, reductive acetylation with acetic anhydride, zinc and pyridine was performed. As a

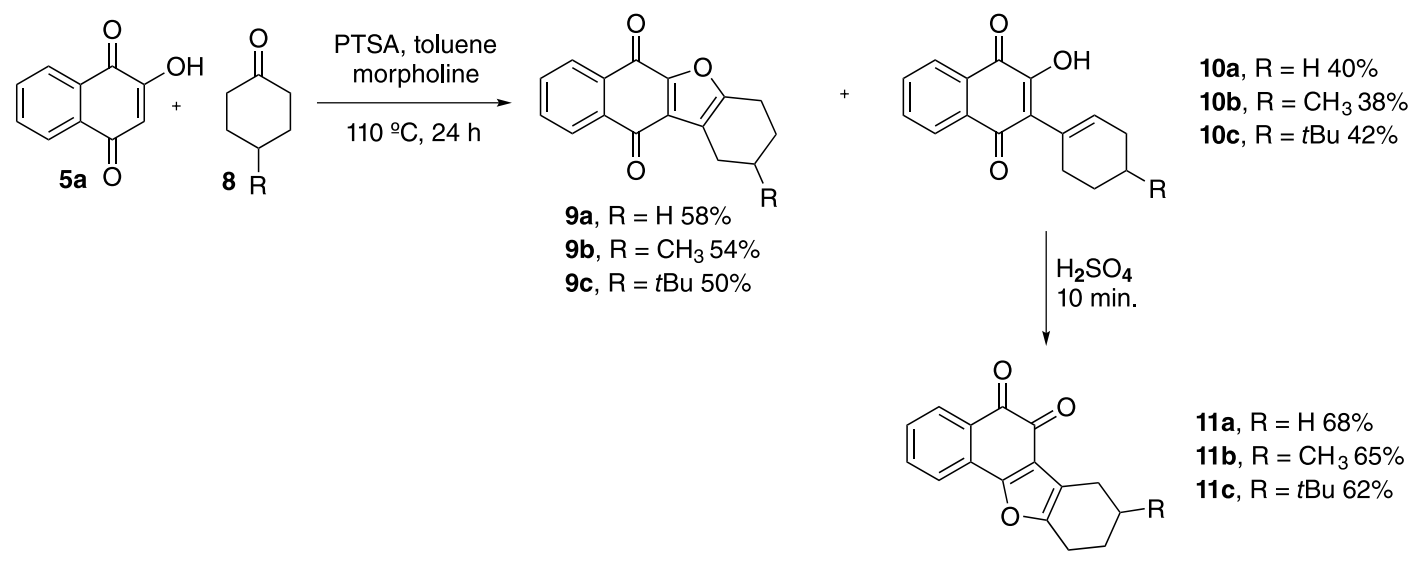

Scheme 2. Synthetic strategy for the preparation of furanaphthoquinones.<smiles>O=C1C=C(O)C(=O)c2ccccc21</smiles><smiles>[R]C1CC=C(N2CCOC(C)(C)C2)CC1</smiles>

Enamine intermediate<smiles>[R]C1[C+]CC(=O)CC1</smiles><smiles>[R]C1CCC([C@H]2C(=O)c3ccccc3C(O)=C2O)[C@H](N2CCOCC2)C1</smiles><smiles>[R]C1CC2CCCC(N3CCOCC3)(Cc3c(c(O)c4ccccc4c3O)O2)C1</smiles><smiles>[R]C1CCc2oc3oc(=O)c4ccccc4c(=O)c3c2C1</smiles>

Scheme 3. Mechanistic proposal for obtaining furan-1,4-naphthoquinones. 
result, acetylated derivatives 12a-12c were obtained with excellent yields that ranged from 92 to $97 \%$ (Scheme 4). On the other hand, to investigate and compare the biological activity against $T$. cruzi, the catalytic hydrogenation of 9a-9c to obtain 13a-13c was performed in a reactor at $27 \mathrm{psi}$, and yields were low (30-35\%) (Scheme 3). Finally, the structures of the new compounds were determined with ${ }^{1} \mathrm{H}$ NMR, ${ }^{13} \mathrm{C}$ NMR, and IR analysis in combination with mass spectrometry (see Supplementary Information section).

\section{Biological assays}

\section{Cell viability}

All naphthoquinone derivatives described were evaluated in vitro against $T$. cruzi. In the LDH release assay, the activity of this intracellular enzyme occurs when there is plasma membrane damage and subsequent cytoplasmic content leakage. In this scenario, after plasma membrane rupture, the cell dies from necrosis. Compounds $9 \mathbf{9 a - 9 c}$, 11a-11c, 12a-12c, and 13a-13c at a concentration of $10 \mu \mathrm{M}$ did not cause cellular toxicity. However, 10a-10c caused toxicity after treatment for $24 \mathrm{~h}$ (Figure 1).

\section{Trypanocide assays}

The resazurin reduction assay was performed on epimastigotes of $T$. cruzi from the Y strain, which were treated for $72 \mathrm{~h}$. Derivatives 9a-9c and 11a-11c at a concentration of $10 \mu \mathrm{M}$ reduced parasite viability compared with non-treated parasites $(\mathrm{CN})$. None of the treatments yielded activity higher than that of the positive controls, $0.05 \%$ Triton X-100 (CP) and $100 \mu \mathrm{M}$ benznidazole (BZ, Sigma-Aldrich, São Paulo, Brazil). However, 9a, 9b, and 11b exerted similar effects to BZ. All six derivatives reduced parasite viability by more than $75 \%$ compared with CN (Figure 2).

The cytotoxicity concentration $\left(\mathrm{CC}_{50}\right)$ estimated for the samples was determined after the treatments, and the concentrations ranged from 0.001 to $100 \mu \mathrm{M}$ for $24 \mathrm{~h}$. The $\mathrm{CC}_{50}$ values calculated for the derivatives were $9 \mathbf{a}(32 \mu \mathrm{M})$, 9b $(177 \mu \mathrm{M}), \mathbf{9 c}(107 \mu \mathrm{M}), \mathbf{1 1 a}(56 \mu \mathrm{M})$ and 11b $(133 \mu \mathrm{M})$ (Figure 3 ). The results show low toxicity for all compounds. Derivatives $\mathbf{9 c}$ and $\mathbf{1 1 b}$ exhibited better results, with $\mathrm{CC}_{50}$ values greater than $100 \mu \mathrm{M}$. Other publication ${ }^{26}$ exhibited naphthofuranquinone analogs with low toxicity compared with benznidazole. However, this furanaphthoquinone series produced via enamine yielded better non-toxic effects.

The half maximal effective concentration $\left(\mathrm{EC}_{50}\right)$ against epimastigote forms was obtained by ranging the concentrations from 0.01 to $100 \mu \mathrm{M}$ for $72 \mathrm{~h}$. The substances exhibited $\mathrm{EC}_{50}$ values of $\mathbf{9 a}(0.1292 \mu \mathrm{M}), \mathbf{9 b}$

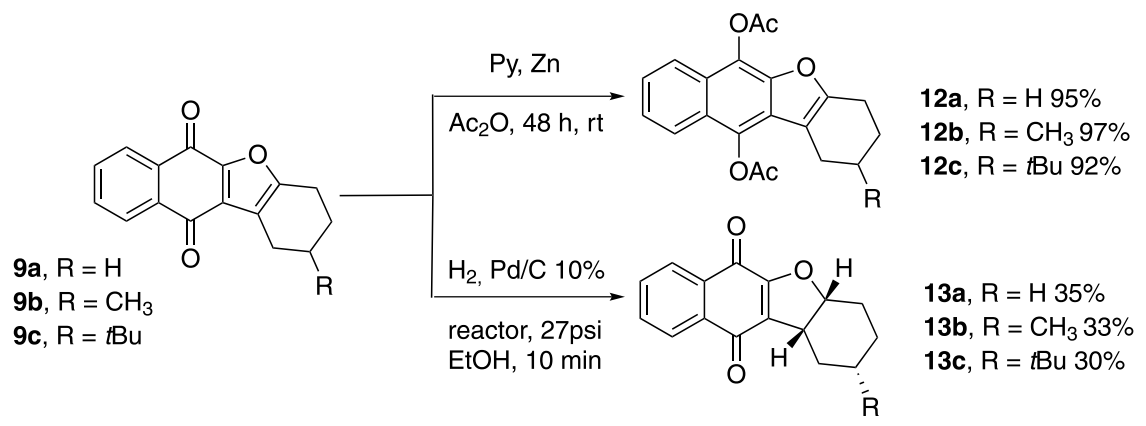

Scheme 4. Reductive acetylation and catalytic hydrogenation of furan-1,4-naphthoquinones.

(a)

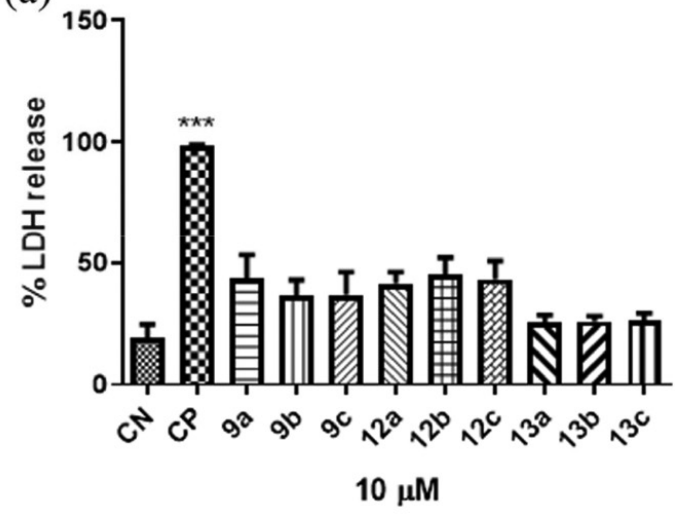

(b)

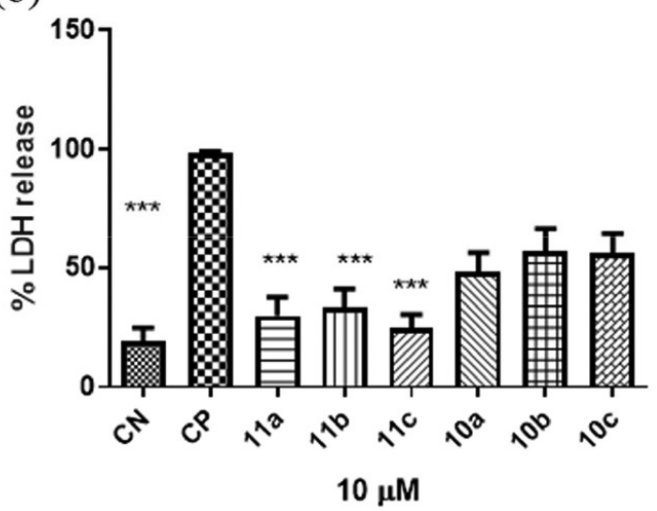

Figure 1. $\mathrm{LDH}$ release assay in peritoneal macrophages. Cell incubation for $24 \mathrm{~h}$. This test was repeated three times on three separate days. CN: untreated cells; CP: cells treated with $0.05 \%$ Triton X-100. *** Denotes $p<0.05$ compared to CN (negative control). 
(a)

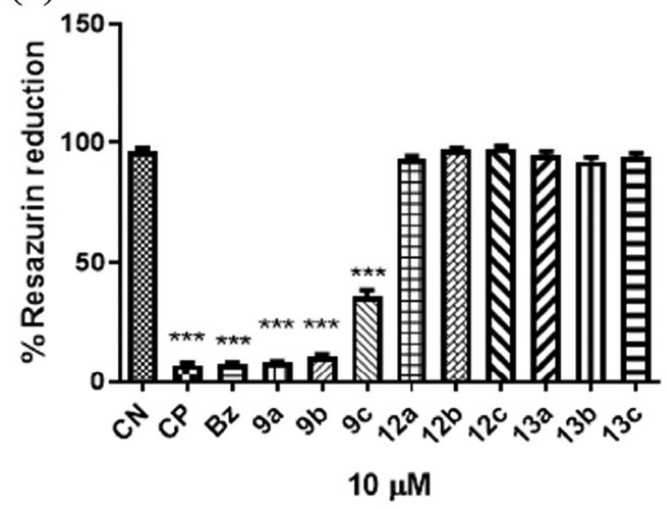

(b)

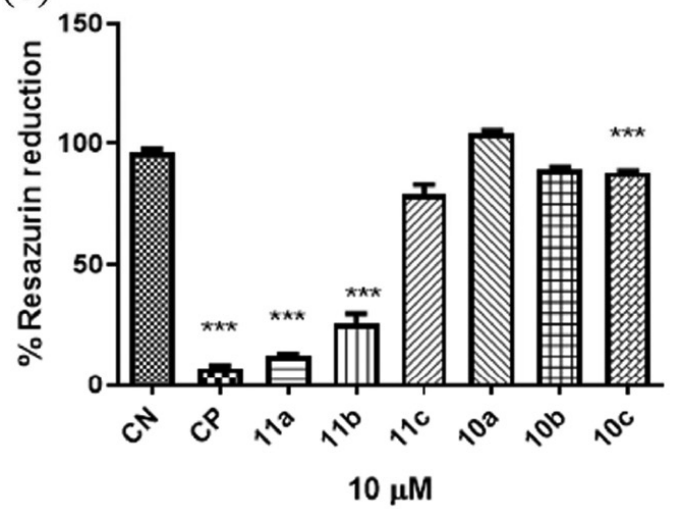

Figure 2. Cellular metabolic assay by reducing resazurin in $T$. cruzi Y strain epimastigotes. The parasites were treated for $72 \mathrm{~h}$. This test was repeated four times on four different days. CN: untreated cells; CP: cells treated with $0.05 \%$ Triton X-100. ***Denotes $p<0.05$ compared to CN (negative control).

$(0.03118 \mu \mathrm{M}), \mathbf{9 c}(0.03391 \mu \mathrm{M}), \mathbf{1 1 a}(0.06437 \mu \mathrm{M})$ and $11 \mathbf{b}(0.07447 \mu \mathrm{M})$ (Figure 4$)$.

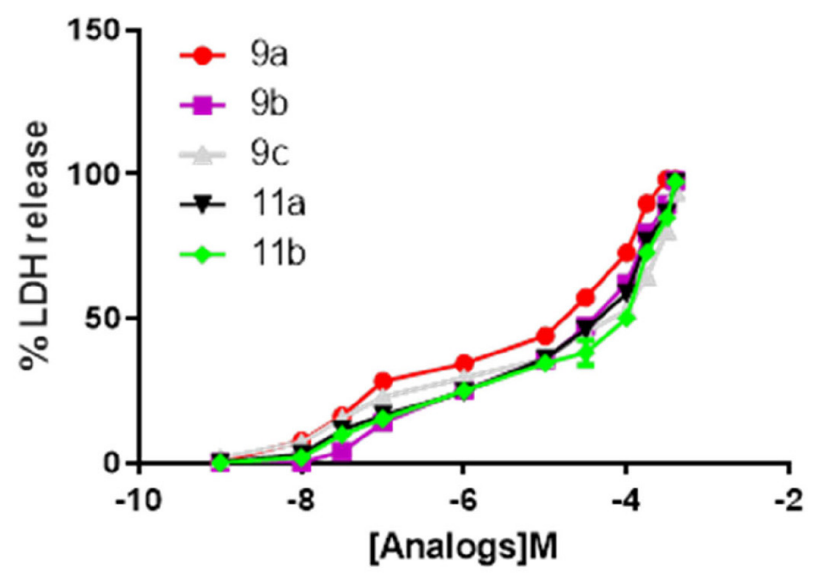

Figure 3. Compound toxicity in peritoneal macrophages. The cells were incubated for $24 \mathrm{~h}$. This test was repeated in triplicate on three different days.

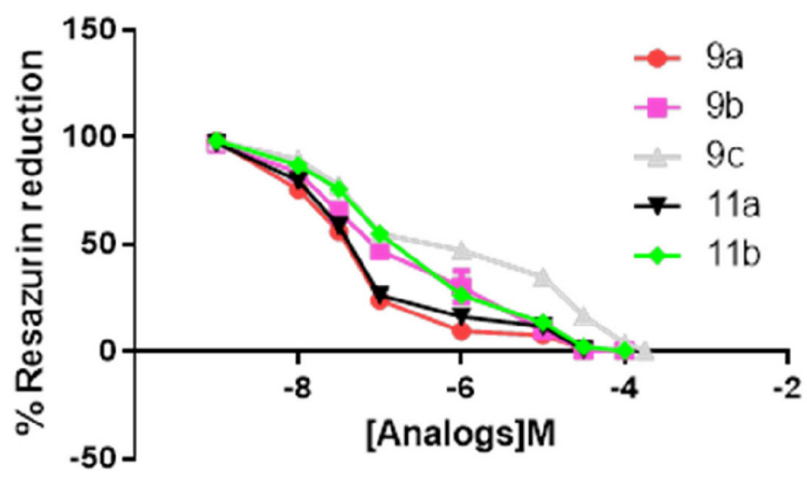

Figure 4. Compound toxicity evaluation in $T$. cruzi epimastigotes. The parasites were incubated for $72 \mathrm{~h}$. This test was repeated in triplicate for three separate days.

The results obtained indicate that analogs with high potency affect parasite viability. Derivatives $\mathbf{9 b}$ and $\mathbf{9 c}$ were the most potent compared with other compounds. $\mathrm{The} \mathrm{IC}_{50}$ (half maximal inhibitory concentration) values for these analogs were in the range of $30 \mu \mathrm{M}$. These substances were tested against trypomastigote forms (Table 1). Treatment with $1 \mu \mathrm{M}$ reduced trypomastigote viability compared to benznidazole. 9b and $9 \mathbf{c}$ produced the highest effects, reducing the parasite numbers by 99 and $95 \%$. However, 11a exhibited an effect similar to benznidazole. Additionally, 9a and 11b had worse effects than benznidazole.

Table 1. Results of the trypanocidal effect on trypomastigote forms

\begin{tabular}{lc}
\hline Compound & Trypomastigote death / \\
\hline Triton X-100 $(0.5 \%)$ & 100 \\
Benznidazole $(100 \mu \mathrm{M})$ & $91 \pm 1$ \\
9a & $73 \pm 6$ \\
9b & $99 \pm 0.6$ \\
9c & $95 \pm 3$ \\
11a & $89 \pm 4$ \\
11b & $84 \pm 2$ \\
\hline
\end{tabular}

In 2006, Silva et al. ${ }^{27}$ described the trypanocidal activity of six naphthofuranquinones, and three of them exhibited $\mathrm{IC}_{50}$ concentration values ranging from 3-20 $\mu \mathrm{M}$ against epimastigote forms after $72 \mathrm{~h}$. These substances caused trypomastigote mortality with $\mathrm{IC}_{50}$ values ranging from 158 and $641 \mu \mathrm{M}$ within $24 \mathrm{~h}$. In 2015, Cardoso et al. ${ }^{26}$ presented prototype 13b with $\mathrm{IC}_{50}$ values lower than $10 \mu \mathrm{M}$ against trypomastigote forms in $24 \mathrm{~h}$. Ferreira et al. ${ }^{28}$ synthesized 16 analogs with $\mathrm{IC}_{50} / 24 \mathrm{~h}$ in the range of $22-63 \mu \mathrm{M}$. Thus, the furanaphthoquinones contained in Table 1 exhibited satisfactory effect, reducing trypomastigotes by $73-99 \%$ at a concentration of $1 \mu \mathrm{M}$.

\section{Selectivity index (SI)}

We calculated the sample selectivity index based on the results described above and compared this index to that of 
the reference drug benznidazole. Although the epimastigote form is infective for the intermediate host (barber), this index serves to indicate whether the sample has the potential to continue experiments in other forms or not. In general, molecules with SI below ten are considered insufficient to proceed in other forms of T. cruzi. All furanaphthoquinoneselected exhibited promising SI values. Compound 9b demonstrated the best value (Table 2).

Table 2. $\mathrm{EC}_{50}, \mathrm{CC}_{50}$ and selectivity index (SI) values

\begin{tabular}{lccc}
\hline Drug & $\begin{array}{c}\mathrm{EC}_{50} \mathrm{Y} \text { strain } / \\
\mu \mathrm{M}\end{array}$ & $\begin{array}{c}\mathrm{CC}_{50} \text { peritoneal } \\
\text { macrophages }(\mathrm{M} 0) \\
/ \mu \mathrm{M}\end{array}$ & $\mathrm{SI}$ \\
\hline Benznidazole & $17 \pm 3$ & $152 \pm 6$ & 938 \\
$\mathbf{9 a}$ & $0.129 \pm 0.011$ & $32 \pm 4$ & 248 \\
$\mathbf{9 b}$ & $0.031 \pm 0,002$ & $177 \pm 4$ & 5709 \\
$\mathbf{9 c}$ & $0.033 \pm 0.004$ & $107 \pm 8$ & 3242 \\
$\mathbf{1 1 a}$ & $0.064 \pm 0.005$ & $56 \pm 3$ & 875 \\
$\mathbf{1 1 b}$ & $0.074 \pm 0.006$ & $133 \pm 9$ & 1794 \\
\hline
\end{tabular}

Evaluation of trypanocidal action; M0: resting. $\mathrm{EC}_{50}$ : half maximal effective concentration; $\mathrm{CC}_{50}$ : cytotoxic concentration; SI: selectivity index.

In the propidium iodide (PI) uptake assay, we measured the fluorescence of this dye when the plasma membrane was damaged, and PI gained access to the nucleus and bound to DNA. This dye is positively loaded and has a size of 636 Daltons. Therefore, PI does not pass spontaneously through the plasma membrane. In this scenario, after plasma membrane rupture, the cell dies from necrosis-a usual scenario of trypanocidal drug action. However, treatment with a concentration of $1 \mu \mathrm{M}$ increased PI fluorescence after $24 \mathrm{~h}$ of continuous treatment (Figure 5).

Thus, we investigated the binding affinities of all six analogs for CYP51 from T. cruzi (CYP51Tc). Sterol $14 \alpha$-demethylase (CYP51) is a cytochrome P450 heme

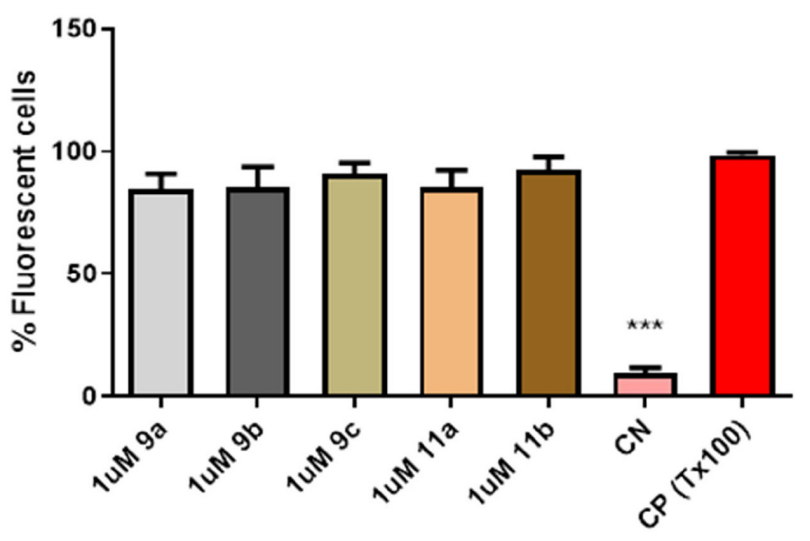

Figure 5. PI uptake assay in epimastigotes. The parasites were cultivated for $24 \mathrm{~h}$. This test was repeated four times on four different days. $\mathrm{CN}$ : untreated cells; CP: cells treated with $0.05 \%$ Triton X-100. ***Denotes $p<0.05$ compared to $\mathrm{CN}$ (negative control). thiolate-containing enzyme associated with ergosterol and ergosterol-like biosynthesis and is a crucial membrane component in T. cruzi. ${ }^{29-31}$ CYP51 activity may be impaired for azoles, resulting in cytostatic or cytotoxic effects. ${ }^{32,33}$ Remarkably, the binding affinities of compounds $\mathbf{9 a}$, 9b, 9c, 11a and 11b to CYP51Tc were $0.07 \pm 0.003$, $0.02 \pm 0.003,0.03 \pm 0.003,0.04 \pm 0.004,0.06 \pm 0.002$, and $0.09 \pm 0.002$, respectively. The antifungal CYP51 inhibitor fluconazole was used as a reference and exhibited a value of $0.1 \pm 0.09$ (Figure 6). All analogs exhibited better affinity to bind with CYP51Tc than fluconazole. 9a exhibits the most potent binding for 9c and 11a. Analogs 11b and 9a showed a moderate effect. In 2019, Dantas et al. ${ }^{34}$ evaluated the anticancer activity of nor- $\beta$-lapachone tethered to $1 H$-1,2,3-triazole (1,2-FNQT) and observed partial inhibition of free radical scavenging activity and poor glycosidase inhibition.

\section{In silico results}

The furanaphthoquinone series compound molecular docking against $T$. cruzi was performed for the protein 14- $\alpha$-lanosterol demethylase (CYP51). The results indicate that residues Ala115, Tyr116, and Leu98 appear essential for the affinity of compounds $9 \mathbf{a}, 9 \mathbf{b}, 9 \mathbf{c}, \mathbf{1 1 a}$, and $11 \mathbf{b}$ to the molecular target. Furthermore, compounds $\mathbf{9 a}$ and $\mathbf{9 c}$ present similar conformational poses, showing the planar aromatic molecular moiety interacting with the heme group $\mathrm{Fe}$ atom by cation- $\pi$ interactions. In addition, both compounds seem to form hydrogen bonds with the Tyr116 residue and hydrophobic interactions with residues Leu98 and Ala115 (Figure 7).

Compounds 11a and 11b exhibited similar poses. Both molecules show the planar aromatic molecular moiety interacting with the heme group $\mathrm{Fe}$ atom by cation- $\pi$ interactions. Both compounds seem to form hydrogen bonds with the Tyr116 residue and with the heme group. Moreover, the molecular poses of both ligands 11a and 11b indicate hydrophobic interactions with residues Leu98 and Ala115 (Figure 7). However, the molecular docking result of compound $9 \mathrm{~b}$ indicates a different pose compared to $\mathbf{9 a}$ and $\mathbf{9 c}$. For ligand $\mathbf{9 b}$, the molecular pose indicates that the intermolecular interactions are mainly hydrogen bonds and hydrophobic interactions. The hydrogen bond interaction is between the cyclic oxygen atom and Tyr116. The hydrophobic interactions are between the ring moieties of compound $\mathbf{9 b}$ and the residues Leu98 and Ala115.

The heat of formation $\left(\Delta \mathrm{H}_{\mathrm{f}}\right)$ was calculated using ligands separated and complexed with protein CYP51 to indicate the affinity between interacting molecules 

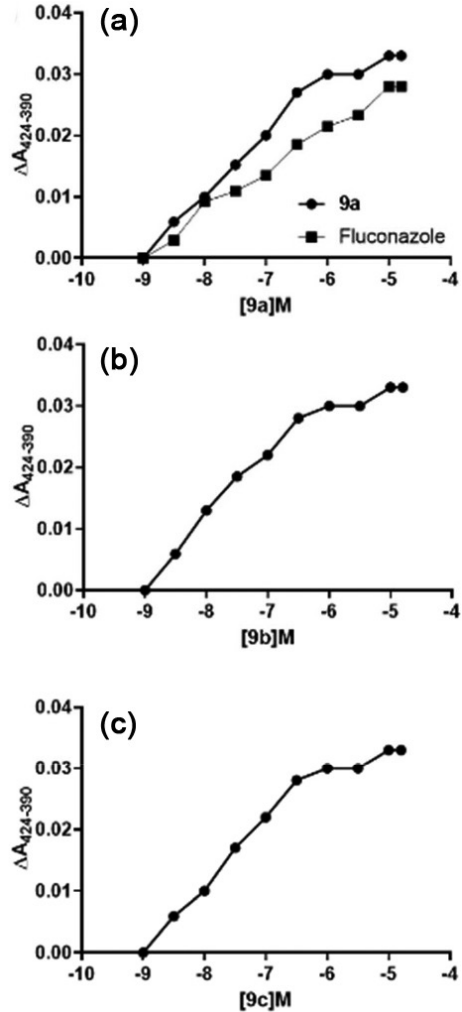
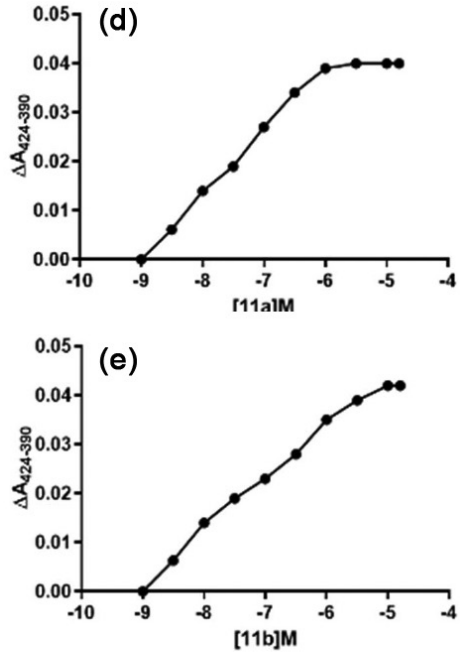
the absorption difference variation derived from the titration of CYP51Tc with increasing furanaphthoquinone analog concentrations. These experiments were performed in triplicate on two distinct days.

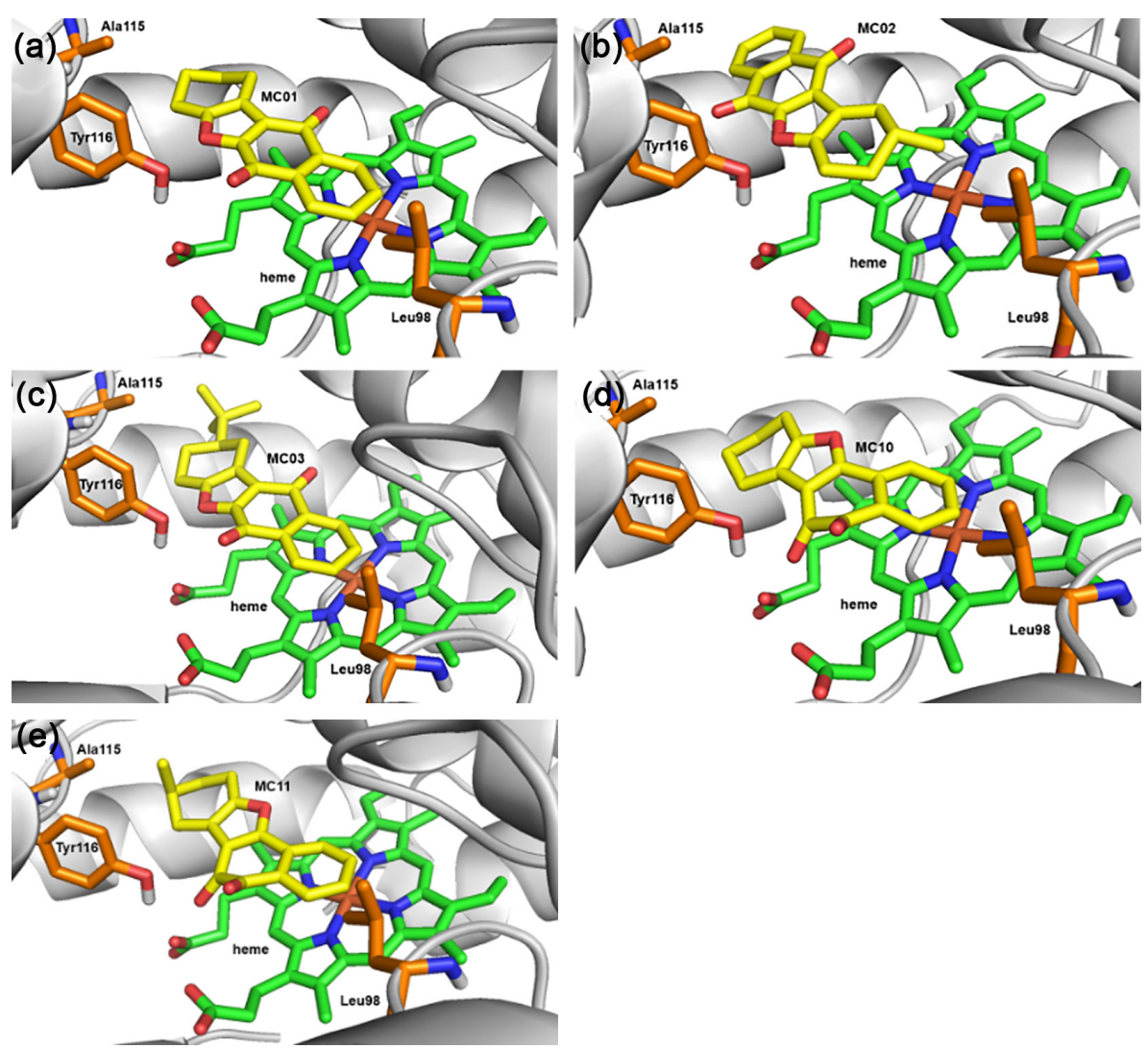

Figure 7. Molecular docking in 14- $\alpha$-lanosterol demethylase (PDB code: 4CK9) for the furanaphthoquinone series compounds against T. cruzi. (a) 9a; (b) $9 \mathrm{~b} ;$; (c) $9 \mathrm{c}$; (d) 11a and (e) 11b. 
(Table 3). The binding enthalpies of the studied ligands are different. The results indicate that $9 \mathbf{b}, 9 \mathbf{c}$, and $11 \mathbf{a}$ have more favorable binding enthalpies with $T$. cruzi CYP51.

Table 3. Heat of formation calculated for binding of the furanaphthoquinone series to T. cruzi 14- $\alpha$-lanosterol demethylase (CYP51)

\begin{tabular}{lc}
\hline Molecular system & Heat of formation ${ }^{\mathrm{a}} /\left(\mathrm{kcal} \mathrm{mol}^{-1}\right)$ \\
\hline CYP51/9a & -11.97 \\
CYP51/9b & -25.44 \\
CYP51/9c & -20.90 \\
CYP51/11a & -19.01 \\
CYP51/11b & -17.52 \\
\hline
\end{tabular}

${ }^{a} \Delta H_{f}=\Delta H_{f}($ complex $)-\Delta H_{f}($ separate $)$.

\section{Conclusions}

In summary, we have developed an operationally simple tandem synthetic protocol for the synthesis of six furanaphthoquinones by enamine intermediates in good yields. Analogs 9a, 9b, 9c, 11a, and 11b exhibited potent and efficacious trypanocide activity against epimastigote forms. These analogs reduced trypomastigote viability by $75 \%$ within $24 \mathrm{~h}$. All of these analogs exhibit trypanocide effects acting on the 14- $\alpha$-lanosterol demethylase enzyme. Thus, these furanaphthoquinone series compounds represent promising candidates to potently and selectively eliminate $T$. cruzi with low toxicity.

\section{Supplementary Information}

Supplementary information is available free of charge at http://jbcs.sbq.org.br as PDF file.

\section{Acknowledgments}

This work was partially supported by FAPERJ grant numbers E-26/203.191/2017, E-26/010.101106/2018, E-26/202.800/2017, E-26/010.003002/2014, E-26/203.246/2017, and E-26/202.353/2019; CNPq 301873/2019-4, 306011/2020-4, 308755/2018-9, and CAPES Financial Code 001.

\section{Author Contributions}

Mariana F. C. Cardoso was responsible for the organic synthesis work; Luana S. M. Forezi for the coordination of organic synthesis work, contributions to manuscript writing; Acácio S. de Souza for the organic synthesis work; Ana F. M. Faria, Raissa M. S. Galvão and Murilo L. Bello for the biological assays work; Fernando C. da Silva for the coordination of organic synthesis work, contributions to manuscript writing; Robson X. Faria for the coordination of biological assays, contributions to manuscript writing; Vitor F. Ferreira for the coordination of organic synthesis work, contributions to manuscript writing.

\section{References}

1. da Silva, F. C.; Ferreira, V. F.; Curr. Org. Synth. 2016, 13, 334.

2. Ahmadi, E. S.; Tajbakhsh, A.; Iranshahy, M.; Asili, J.; Kretschmer, N.; Shakeri, A.; Sahebkar, A.; Mini-Rev. Med. Chem. 2020, 20, 2019.

3. Janeczko, M.; Demchuk, O. M.; Strzelecka, D.; Kubiński, K.; Masłyk, M.; Eur. J. Med. Chem. 2016, 124, 1019.

4. Aminin, D.; Polonik, S.; Chem. Pharm. Bull. 2020, 68, 46.

5. Jentzsch, J.; Koko, W. S.; Al Nasr, I. S.; Khan, T. A.; Schobert, R.; Ersfeld, K.; Biersack, B.; Chem. Biodiversity 2020, 17, e1900597.

6. López-Lira, C.; Tapia, R. A.; Herrera, A.; Lapier, M.; Maya, J. D.; Soto-Delgado, J.; Oliver, A. G.; Lappin, A. G.; Uriarte, E.; Bioorg. Chem. 2021, 111, 104823.

7. González, A.; Becerra, N.; Kashif, M.; González, M.; Cerecetto, H.; Aguilera, E.; Nogueda-Torres, B.; Chacón-Vargas, K. F.; Zarate-Ramos, J. J.; Castillo-Velázquez, U.; Salas, C. O.; Rivera, G.; Vázquez, K.; Med. Chem. Res. 2020, 29, 665.

8. Bourguignon, S. C.; Cavalcanti, D. F. B.; Souza, A. M. T.; Castro, H. C.; Rodrigues, C. R.; Albuquerque, M. G.; Santos, D. O.; Silva, G. G.; da Silva, F. C.; Ferreira, V. F.; Pinho, R. T.; Alves, C. R.; Exp. Parasitol. 2011, 127, 160.

9. Bourguignon, S. C.; Castro, H. C.; Santos, D. O.; Alves, C. R.; Ferreira, V. F.; Gama, I. L.; da Silva, F. C.; Silva, W. S.; Pinho, R. T.; Exp. Parasitol. 2009, 122, 91.

10. Bian, J.; Deng, B.; Xu, L.; Xu, X.; Wang, N.; Hu, T.; Yao, Z.; Du, J.; Yang, L.; Lei, Y.; Li, X.; Sun, H.; Zhang, X.; You, Q.; Eur. J. Med. Chem. 2014, 82, 56.

11. Kobayashi, K.; Tanaka, K.; Uneda, T.; Maeda, K.; Morikawa, O.; Konishi, H.; Synthesis 1998, 1243.

12. Kakisawa, H.; Tateishi, M.; Bull. Chem. Soc. Jpn. 1970, 43, 824.

13. Tateishi, M.; Kusumi, T.; Kakisawa, H.; Tetrahedron 1971, 27 , 237.

14. Omote, Y.; Tomotake, A.; Kashima, C.; J. Chem. Soc., Perkin Trans. 1 1988, 151.

15. SoftMax Pro, version 5.1; Molecular Devices, LLC, United States of America, 2010.

16. GraphPad Prism, version 5.00; GraphPad Software, Inc.; USA, 2008.

17. Cornell, T.; Hutchison, G.; Avogadro, version 1.1.2; University of Pittsburgh, USA, 2018.

18. Hanwell, M. D.; Curtis, D. E.; Lonie, D. C.; Vandermeersch, T.; Zurek, E.; Hutchison, G. R.; J. Cheminform. 2012, 4, 17. 
19. MOPAC2016; Stewart Computational Chemistry, Colorado Springs, CO, USA, 2016, available at http://OpenMOPAC.net, accessed in October 2021.

20. Molegro Virtual Docker, version 6.0; Molexus IVS, Denmark, 2013.

21. The PyMOL Molecular Graphics System; Pymol, version 2.0; Schrödinger, LLC, USA, 2019.

22. Klamt, A.; Schüümann, G.; J. Chem. Soc., Perkin Trans. 2 1993, 799.

23. Stewart, J. J. P.; J. Mol. Model. 2013, 19, 1.

24. Reichstein, A.; Vortherms, S.; Bannwitz, S.; Tentrop, J.; Prinz, H.; Müller. K.; J. Med. Chem. 2012, 55, 7273.

25. Ma, X.; Huang, X.; Moore, Z.; Huang, G.; Kilgore, J. A.; Wang, Y.; Hammer, S.; Williams, N. S.; Boothman, D. A.; Gao, J.; J. Controlled Release 2014, 200, 201.

26. Cardoso, M. F. C.; Salomão, K.; Bombaça, A. C.; Rocha, D. R.; da Silva, F. C.; Cavaleiro, J. A. S.; de Castro, S. L.; Ferreira, V. F.; Bioorg Med. Chem. 2015, 23, 4763.
27. Silva, R. S. F.; Costa, E. M.; Trindade, U. L. T.; Teixeira, D. V.; Pinto, M. C. F. R.; Santos, G. L.; Malta, V. R. S.; de Simone, C. A.; Pinto, A. V.; de Castro, S. L.; Eur J. Med. Chem. 2006, $41,526$.

28. Ferreira, S. B.; Salomão, K.; da Silva, F. C.; Pinto, A. V.; Kaiser, C. R.; Pinto, A. C.; Ferreira, V. F.; de Castro, S. L.; Eur. J. Med. Chem. 2011, 46, 3071.

29. Aoyama, Y.; Front. Biosci. 2005, 10, 1546.

30. Furlong, S. T.; Exp. Parasitol. 1989, 68, 482.

31. Roberts, C. W.; McLeod, R.; Rice, D. W.; Ginger, M.; Chance, M. L.; Goad, L. J.; Mol. Biochem. Parasitol. 2003, 126, 129.

32. Kolb, H. C.; Finn, M. G.; Sharpless, K. B.; Angew. Chem., Int. Ed. 2001, 40, 2004

33. Wu, P.; Fokin, V. V.; Aldrichim. Acta 2007, 40, 7.

34. Dantas, R. F.; Senger, M. R.; Cardoso, M. F. C.; Ferreira, V. F.; de Souza, M. C. B. V.; da Silva, F. C.; Silva Jr., F. P.; Med. Chem. Res. 2019, 28, 1579. 